\title{
Penerapan Humanistik Melalui Non-Verbal Reinforcement ditinjau dari Percaya Diri Siswa dalam Pembelajaran
}

\author{
Veni Veronica Siregar ${ }^{1 *}$, Suyadi$^{2}$, Ragil Dian Purnama Putri ${ }^{3}$
}

${ }^{123}$ Jurusan Pendidikan Guru Madrasah Ibtidaiyah, Universitas Islam Negeri Sunan Kalijaga, Indonesia

\section{A R T I C L E IN F O Article history: \\ Received 1 Januari 2021 Received in revised form 30 Januari 2021 \\ Accepted 1 Maret 2021 \\ Available online 8 April 2021}

\section{Kata Kunci:}

humanistik, percaya diri siswa

Keywords:

humanistic, student selfconfidence

\begin{abstract}
A B S T R A K
Penggunaan metode pembelajaran yang kurang tepat dapat menyebabkan kepercayaan diri siswa didalam pelaksanaan pembelajaran menjadi rendah, sehingga diperlukan metode yang dapat meningkatkan kepercayaan diri siswa. Penelitian ini bertujuan untuk menganalisis penerapan humanistik melalui non verbal reinforcement ditinjau dari percaya diri siswa dalam pembelajaran. Penelitian ini merupakan penelitian lapangan. Subjek penelitian ini adalah kepercayaan diri siswa dalam pembelajaran, sedangkan objek penelitian ini adalah siswa dan guru. Metode pengumpulan data yang digunakan adalah studi kasus. Data yang diperoleh dianalisis dengan teknik analisis data statistik deskriptif kualitatif. Hasil temuan penelitian ini mengungkapkan bahwa humanistik dengan melalui verbal reinforcement mampu memberikan dampak yang sangat baik terhadap siswa dalam pembelajaran. Sehingga dapat disimpulkan bahwa penerapan humanistik melalui non verbal reinforcement dinyatakan dapat berpengaruh terhadap percaya diri siswa dalam pembelajaran. Implikasi penelitian ini adalah siswa akan merasa nyaman saat belajar, merasa dihargai tidak adanya rasa
\end{abstract} perbedaan prilaku yang dilakukan guru terhadap siswa, siswa bebas dalam mengeskplorasi rasa keingintahuannya tanpa ada rasa ancaman.

\section{A B S T R A C T}

The use of inaccurate learning methods can cause student self-confidence in the implementation of learning to be low, so a method is needed that can increase student self-confidence. This study aims to analyze the application of humanism through non-verbal reinforcement in terms of students' confidence in learning. This research is a field research. The subjects of this study were students' self-confidence in learning, while the objects of this study were students and teachers. The data collection method used is a case study. The data obtained were analyzed using qualitative descriptive statistical data analysis techniques. The findings of this study reveal that humanistic through verbal reinforcement is able to have a very good impact on students in learning. So it can be concluded that the application of humanism through non-verbal reinforcement is stated to have an effect on students' confidence in learning. The implication of this research is that students will feel comfortable while studying, feel appreciated there is no sense of differences in the behavior of the teacher towards students, students are free to explore their curiosity without any sense of threat.

\section{Pendahuluan}

Pendidikan tidak pernah luput dari setiap individu yang melekat menjadi satu ranah dalam kehidupan. Setiap orang memerlukan pendidikan baik pendidikan sekolah, lingkungan, dan keluarga. Hakekat dari suatu pendidikan yaitu suatu proses pemanusiawian manusia, pengangkatan manusia ke taraf insani. Dalam prespektif humanistik yaitu dimana menentukan potensi peserta didik dalam proses tumbuh kembang, memberikan hak bebas terhadap jalan hidupnya. Dalam memahami humanistik pendidikan mengarahkan objek peserta didik yang mempunyai fikiran induktif menganggap peserta didik sebagai subjek yang merdeka guna menetapkan tujuan hidupnya, peserta 
didik dituntun agar memiliki sifat berani dan bertanggung jawab atas dirinya (Elviana \& Murdiono, 2017; Nursa'ban, 2013; Sari \& Syamsi, 2015).

Pemanusiawian manusia (humanisasi) pada hakekatnya pendidikan merupakan tombak terbaik dalam menciptakan prilaku humanisasi (Hartiningsih, 2015; Kristiyani, 2015; Ponorogo, 2016). Hal tersebut sering tidak terwujud karena terjebak pada nilai penghancuran kemanusiaan, hal ini terkadang adanya perbedaan antara konsep dengan pelaksanaan, hal ini yang mengakibatkan kegagalan pendidikan dalam mencapai misi suci untuk mengangkat harkat dan martabat manusia sehingga pendidikan belum berhasil memanusiakan manusia. Pribadi-pribadi akan berkembang secara optimal dan relatif baik jika berada didalam lingkungan suasana yang didalamnya penuh cinta, hati yang tulus, hati yang penuh pengertian serta dihargai keberadaanya (Amran et al., 2019; Rizal \& Munip, 2017; Suwarna \& Jatirahayu, 2013).

Tugas pendidikan di era Revolusi Industri 4.0 adalah menguatkan pendidikan karakter dengan prinsip bahwa karakter dapat berubah sesuai dengan kesempatan dan lingkungan belajar yang diciptakannya (Labudasari \& Rochmah, 2018; Suwarna \& Jatirahayu, 2013; Widiarti, 2013). Lebih lanjut pendidikan tingkah laku harus menjadi pijakan kuat di tengah perkembangan teknologi dan arus percepatan informasi. Menjadi seorang pendidik atau guru tidaklah mudah, guru harus memiliki ketrampilan dasar yang dimilikinya yaitu keterampilan dalam memberi penguatan (reinforcement) guna memotifasi siswa untuk meningkatkan kemampuan belajar siswa, penguatan dibutuhkan dalam proses pembelajaran karena merupakan suatu penghargaan yang dapat menimbulkan rasa semangat dalam belajar penguatan befungsi sebagai ganjaran kepada siswa sehingga adanya rasa kepercaan diri yang menjadikan siswa selalu berpartisipan dalam proses pembelajaran (Anggraini \& Perdana, 2019; Gaol et al., 2017; Vita, 2016).

Guru piguran yang sangat penting dalam memberikan penguatan terhadap peserta didik, sehingga sudah mestinya guru sudah menerapkan pendekatan dalam proses pembelajaran untuk memotivasi siswa. Penguatan dibagi menjadi dua yaitu penguatan verbal dan nonverbal, verval adalah penguatan yang melalui ungkapan sedangkan non verbal penguatan pendekatan, isyarat dan sentuhan dengan mengunakan pendekatan dapat menunjanh proses pembelajaran lebih efektif dan komunikatif (Dardiri et al., 2017; Karom et al., 2014; Khofiatun et al., 2016).

Namun kenyataannya, berdasarkan hasil observasi di SD Negeri Kepahiang guru yang merupakan penguatan yang merespon secara positif dengan suatu tingkah laku tertentu memungkinkan siswa menimbulkan tingkah laku tersebut kembali, tetapi masih ada guru yang tidak mengunakan pendekatan-pendekatan kepada siswa. Contoh penguatan tersebut yaitu siswa yang memiliki prilaku yang cendrung takut dalam hal menyampaikan pendapat sehingga siswa tersebut tidak dapat menjadikan dirinya optimal dalam pembelajaran, dan ada siswa yang cendrung lebih tertutup pribadinya sehingga menjadika siswa tersebut lebih suka menyendiri. Guru hanya memberikan pembelajaran yang bertujuan agar siswa pandai dalam pengetahuan akan tetapi lupa akan kepribadian karakter yang harus juga ditanama kepada peserta didik.

Pendidikan bukan hanya persoal mencerdaskan saja tetapi membentuk peserta didik memiliki karakter, karakter dalam pendidikan menjadi bagian penting sehingga pemerintah menjadi acuan untuk mewujutkan suatu bangsa yang menjadi amat pancasila pembukaan undang-undang yang menjadi persoalan pada masa sekarang misalnya kurangnya rasa kepemilikian terhadap sesama masyarakat maupun negera, sehingga kurangnya etika terhadap bangsa (Khodijah, 2018; Saputro \& Soeharto, 2015; Surya, 2017). Setiap manusia memilki karakter kepribadian berbeda sifat khas dari diri seseorang yang dikatakan sebagai karakter, karakter seseorang terbentuk dari berbagai faktor misalnya diterima dari lingkungan, keluarga dan juga sejak lahir (Irawan, 2016; Morelent \& Syofiani, 2018; Surya, 2017). Selain pendapat tersebut ada juga beberapa orang yang berpendapat bahwa karakterisrik sudah melekat dalam jiwa seseorang sejak lahir, jika pembawaan jiwa baik maka akan memiliki karakter jiwa yang baik dan sebaliknya jika memiliki jiwa yang buruk maka akan menghasilkan karakter yang buruk.

Karakter memiliki makna arti sebagai simbol jati diri seseorang yang akan menjadi penilaian bagi orang lain terhadap apa yang dilakukan, jika seseorang tidak memiliki karakter maka akan menciptakan berbagai kegalauan dan kerusuhan dalam pola pikir dan pola sikap masyarakat (Kamar et al., 2020; Maulida, M., Wati \& An'nur, 2015; Yulianti, 2016). Didalam pendidikan karakter diartikan sebagai usaha menanamkan kebiasaan-kebiasaan yang baik (habitutation) sehingga peserta didik mampu bersikap dan bertindak berdasarkan nilai-nilai yang telah menjadi kepribadiannya (Kristiyani, 
2015; Lestariningsih \& Suardiman, 2017; Putra, 2017). Salah satu karakter yang dapat ditanamkan kepada siswa adalah percaya diri.

Kemampuan dalam berbicara merupakan bentuk tindakan yang mencerminkan karakter percaya diri, setiap manusia memiliki kenyaman dalam dirinya, sama halnya seperti peserta didik dalam merinteraksi dengan teman sebananya yang tidak semua siswa memiliki karakter pemberani sehingga menjadikan dirinya percaya diri. Percaya diri merupakan suatu keyakinan dalam jiwa pada manusia bahwa tantangan hidup harus dihadapi dengan melakukan tindakan (Anggraini \& Perdana, 2019; Suryani \& Gunawan, 2018; Vita, 2016). Kepercayaan diri dapat diartikan sebagai keyakinan seseorang akan suatu kemampuan yang dimilikinya untuk melakukan suatu hal yang ditunjukan oleh dirinya sendiri tanpa adanya keterpaksaan seseorang yang memiliki rasa percaya diri akan merasa lebih mampu dalam mencapai tujuan dan menjalankan apapun dalam menjalani kehidupan (Kamar et al., 2020; Maulida, M., Wati \& An'nur, 2015; Yulianti, 2016). Untuk meningkatkan kepercayaan diri siswa maka, solusi yang diberikan oleh peneliti adalah penerapan metode humanistik.

Penelitan yang dilakukan sebelumnya dengan metode kualitatif lapangan menghasilkan data bahwa strategi, metode, serta perilaku guru dalam pengimplemetasian sangat penting dengan adanya penggunaan metode humanistik yang diterapkan dalam pembelajaran memberikan dampak positif bagi pembelajaran. Adapun dampak positif siswa melaksanakan pembelajaran dengan penerapan metode humanistik dapat membuat siswa merasa nyaman saat belajar, merasa dihargai tidak adanya rasa perbedaan prilaku yang lakukan guru terhadap siswa, siswa bebas dalam mengeskplorasi rasa keingintahuannya tanpa ada rasa ancaman. Selain itu, penelitian lain dalam penulisannya terdapat hasil bahwa psikologi humanistik sangat relevan dengan dunia pendidikan karena aliran ini mendorong peningkatan kualitas manusia, sejalan dengan peneliti lakukan yaitu dengan adanya penerapan humanistik non verbal dalam pendidikan menjadikan peserta didik percaya diri yang melahirkan peningkatan mutu kehidupan kualitas manusia (Kristiyani, 2015; Lestariningsih \& Suardiman, 2017; Mudlofir, 2013).

Penelitian ini didukung dengan beberapa penelitian yang relevan, seperti: (1) penelitian yang dilakukan oleh (Vita, 2016), yang memperoleh hasil yaitu terjadi peningkatan sikap percaya diri melalui dreams book bagi siswa; (2) penelitian yang dilakukan oleh (Suryani \& Gunawan, 2018), yang memperoleh hasil yaitu ada hubungan pemahaman diri dengan sikap percaya diri pada siswa; (3) penelitian yang dilakukan oleh (Anggraini \& Perdana, 2019), yang memperoleh hasil yaitu hubungan sikap dan percaya diri siswa pada mata pelajaran IPA. Tujuan dilaksanakannya penelitian ini adalah untuk menganalisis penerapan humanistik melalui non verbal reinforcement ditinjau dari percaya diri siswa dalam pembelajaran di SD Negeri Kepahiang.

\section{Metode}

Penelitian yang dilakukan peneliti dengan menggunakan jenis penelitian lapangan menggunakan pendekatan yaitu kualitatif (Defiyanti \& Sumarni, 2019; Pebriana, 2018; Tisnasari, 2017). Penelitian juga dikatakan penelitian lapangan karena pada proses penelitian yang dilakukan peneliti langsung terjun kelapangan yang artinya disini penulis langsung terjun kelapangan sehingga terlibat secara langsung dengan masyarakat setempat. Penelitian lapangan dilakukan bertujuan agar penulis dapat mengetahui dengan pasti, fenomena dan fakta apa yang sebenarnya terjadi di lapangan.

Didalam kajian ini, objek dari penelitian ini adalah penguatan yang dilakukan oleh pendidik dalam memanusiakan manusia yang disini sebagai murid, kemudian dari penedekatan non verbal apakah dapat membentuk karakter murid yang percaya diri. Penulis juga mencari bahan penelitian dengan cara mengobservasi dan mewawancarai dewan guru yang berterkait sebagai wali kelas dengan menerapkan pendekatan Non-Verbal. Observasi atau pengamatan itu meliputi kegiatan pemusatan perhatian terhadap suatu obyek dengan menggunakan seluruh alat indera.

Peneliti melakukan dengan pendekatan guru dalam pembelajaran daring. Wawancara juga sangat diperlukan karena penulis dapat menemukan informasi yang lebih jelas terkait pendekatanpendektan yang dilakukan pendidik guna menerapkan humanistik dalam pengajaran. Wawancara adalah suatu percakapan yang diarahkan pada suatu masalah tertentu. ini merupakan proses tanya jawab lisan, terdapat dua orang atau lebih secara fisik atau non fisik. Terdapat dua pihak dengan kedudukan yang berbeda dalam proses wawancara. dimana Pihak pertama berfungsi sebagai penanya, sedangkan pihak kedua bertugas sebagai pemberi informasi. 
Selanjutnya, peneliti juga mengumpulkan sumber referensi dari berbagai refereinsi untuk melakukan analisis permasalahan non verbal dalam humanistik yang bertujuan menumbuhkan rasa percaya diri peserta didik. Teknik analisis data yang digunakan oleh penulis pada penelitian ini dengan melalui empat sub proses, yakni pengumpulan data, reduksi data, display data dan verifikasi data..

\section{Hasil dan Pembahasan}

Berdasarkan hasil penelitian yang dilakukan menjelaskan mendapatkan beberapa hasil temuan, dimana guru kelas 1 melakukan komunikasi menggunakan aplikasi WhatsApp. Hasil penelitian menunjukkan bahwa dalam penerapan pembelajaran secara langsung guru memberikan reward kepada siswa berupa permen sehingga guru selalu menyiapkan permen. Reward tersebut selalu disiapkan oleh guru yang akan diberikan sebagai reward kepada siswa yang sudah berhasil menyelesaikan tugas dan mendapatkan nilai baik. Misalnya kegiatan yang dilakukan yaitu guru memberikan soal sederhana kepada siswa. Dari soal yang diberikan maka siswa yang berhasil menyelesaikan makan mendapatkan reward dari guru. Bagi siswa yang belum berhasil menyelesaikan soal dengan baik maka guru juga memberikan reward yaitu berupa dukungan tepuk tangan agar belum bagi siswa yang berhasil tidak putus asa dan bisa lebih semangat lagi.

Selain hasil penelitian di atas juga terdapat hasil wawancara dengan Ibu Karneli sebagai wali kelas 1. Dari hasil penelitian mendapatkan data bahwa di dalam pembelajaran memberikan reward kepada siswa yang sudah mencapai tujuan. Reward hadiah inilah yang biasa disebut dengan respon kepada siswa. Hal tersebut tidak jauh berbeda dengan guru kelas 2 yang memiliki cara tersendiri dalam menerapkan humanistik. Adapun hasil penelitian yang didapatkan melalui WhatsApp yaitu guru kelas 2 mengapresiasi siswa yang sudah mengerjakan tugas dengan memberikan apresiasi "Bagus, kamu sudah rajin dalam mengerjakan tugas, jangan lupa dipertahankan dan selalu semangat belajarnya". Hal tersebut selalu dilakukan guru untuk mengapresiasi siswa yang sudah disiplin mengerjakan tugas maupun dalam belajar. Disiplin siswa maka akan menumbuhkan siswa untuk bertanggung jawab, jujur, percaya diri, dan membangun kreatifitas dirinya. Penelitain tersebut juga didukung hasil wawancara dengan ibu Kholifah yang dapat disimpulkan bahwa mengapresiasi bukan hanya dari hasil pembelajaran saja tetapi juga mengapresiasi siswa melalui kedisplinan. Kedisplinan dapat berdampak baik bagi siswa yaitu dengan mengapresiasi siswa yang maju ke depan misalnya memberikan apresiasi berupa "bagus sekali, sudah baik sudah maju ke depan."

Selanjutnya untuk kelas 3 berbeda dengan kelas 1 dan kelas 2, dimana guru lebih menekankan pada siswa. Adapun hasil wawancara mendapatkan hasil bahwa siswa kurang percaya diri dalam pembelajaran. Hal tersebut karena mental siswa yang takut salah dan faktor lingkungan. Selain itu, wawancara dengan Ibu Ningsih juga mendapatkan kesimpulan bahwa interaksi siswa terhadap guru dapat mempengaruhi siswa dengan kata-kata. Siswa biasanya dapat mengingat kata-kata dengan mudah terutama kata-kata yang berkesan bagi dirinya. Oleh karena itu, ucapan dan perlakuan yang baik akan berdampak baik pula bagi siswa. Pendekatan yang dilakukan yaitu dpat dilakukan dengan cara mencari tahu apa penyebab dan menyelesaikan agar siswa tersebut tidak berlarut-larut menjadi pribadi yang tidak percaya diri.

Humanistik memiliki makna kata humanis kemanusiaan yang memang lahir secara alamiah, setiap manusia yang dilahirkan dibumi memiliki rasa kemanusaian yang sudah menjadi fitrah manusia dan bagaimana caranya agar kemanusiaan itu tetap ada. Memfokuskan terhadap isi yang dipelajari dalam pembelajaran dibandingkan dengan proses dalam pembelajaran merupakan teori humanistik, sehingga lebih menekankan kepada konsep pendidikan dalam menjadikan manusia yang dicita-citakan (Elviana \& Murdiono, 2017; Nursa'ban, 2013; Sari \& Syamsi, 2015). Humanistik meninjau manusia seperti subyek dalam bebas menentukan arah hidupnya. seorang manusia memiliki bertanggungj awab terhadap hidup diri sendir dan orang laini. Pendidikan humanistik dimana selaku manusia melakukan interaksi dengan komunikai dan dengan relasi baik antar individu pribadi sendiri dan pribadi dan kelompok pada suatu perkumpulan didalam sekolah. Teori humanistik ini sangat pesat sehingga menghasilkan pendidikan yang baik jika berlandas oleh rasa saling mecintai, menyanyangi antar murid. lingkungan yang memberikan suasana dengan rasa penuh cinta, penuh pengertian (understanding heart) serta adanya ikatan dalam diri pribadi yang efektif (personal relationship) maka akan berdampak bagi Pribadi-pribadi yang menjadi diri berkembang secara optimal dan relatif. 
Dari hasil penelitian yang dilakukan maka guru sudah menerapkan karakter percaya diri kepada siswa. Berbagai cara dilakukan oleh guru di sekolah dasar yaitu diantaranya yaitu memberikan stimulus kepada siswa. Cara lain yaitu mengapresiasi siswa yang dapat menyelesaikan tugas baik dan tertib. Terakhir siswa yang lain juga diberikan semangat agar lebih termotivasi dalam belajar. Penguatan non verbal berarti suatu penguatan yang diberikan oleh pendidik melalui ungkapan bahasa isyarat dengan menggunakan bahasa tubuh. Penguatan non verbal dapat dilakukan dengan menggunakan gerakan yang mendekati siswa, penguatan ini dapat juga diterapkan pendidik dengan memberi berupa suatu aktivitas dan tugas pembelajaran yang mengasikan. Penguatan yang berupa mimik dan gerakan-gerakan badan (gesture) misalnya ekspresi wajah yang manis dan bangga, senyuman, kerlingan mata, anggukan kepala, acungan jempol dan tepuk tangan. Mendekatnya pendidik kepada murid dengan menyatakan suatu perhatian atau berupa kesenangannya terhadap pekerjaannya, perbuatan prilaku atau penampilan siswa sehingga murid merasa bahwa pendidik memang memberikan perhatian dan penguatan murid yang artinya menghargai pekerjaan siswa. Hasil penelitian yang dilakukan peneliti bahwa penguatan non-verbal ini sudah terlaksana dengan baik. Hal tersebut terbukti dengan reward yang diberikan guru kepada siswa. Reward tersebut yaitu berupa hadiah makanan, tepuk tangan, maupun ungkapan-ungkapan yang dapat memotivasi siswa. Hal sudah sesuai dengan teori yang diejalskan sebelumnya.

Penguatan juga dapat diterapkan dengan sentuhan, seperti tindakan menepuk-nepuk bahu atau pundak murid, menjabat tangan dengan siswa. Penguatan Berupa Simbol atau Benda Penguatan jenis ini misalnya seperti komentar yang tertulis pada buku murud, bergambar, bintang plastik, dan bisa berupa hadiah benda. dan yang terakhir, jangan sering digunakan karena dapat memicu kebiasaan yang selalu mengharapkan imbalan. Penjelasan di atas peneliti memandang bahwa suatu penguatan nonverbal merupakan penguatan yang berupa suatu tindakan sentuhan. sentuhan dilakukan sebagai bentuk penghargaan pendidik kepada murid dengan tingkah laku murid dan atas kinerja murid dengan bertujuan yakitu suatu penguat terhadap murid terhadap apa yang telah dilakukannya, non verbal juga dapat diberikan oleh pendidik berupa gerakan isyarat bahasa tubuh, yaitu berupa acungan jempol, mendekati siswa yang sedang kesulitan dalam mengerjakan tugasnya, memberikan pelukan terhadap tingkah laku yang kurang baik atau kurang berprestasi supaya siswa tetap mempunyai semangat dalam belajar dan kepercayaan diri.

Karakter memiliki makna arti sebagai simbol jati diri seseorang yang akan menjadi penilaian bagi orang lain terhadap apa yang dilakukan, jika seseorang tidak memiliki karakter maka akan menciptakan berbagai kegalauan dan kerusuhan dalam pola pikir dan pola sikap masyarakat (Kamar et al., 2020; Maulida, M., Wati \& An'nur, 2015; Yulianti, 2016). Didalam pendidikan karakter diartikan sebagai usaha menanamkan kebiasaan-kebiasaan yang baik (habitutation) sehingga peserta didik mampu bersikap dan bertindak berdasarkan nilai-nilai yang telah menjadi kepribadiannya (Kristiyani, 2015; Lestariningsih \& Suardiman, 2017; Putra, 2017). Salah satu karakter yang dapat ditanamkan kepada siswa adalah percaya diri.

Kemampuan dalam berbicara merupakan bentuk tindakan yang mencerminkan karakter percaya diri, setiap manusia memiliki kenyaman dalam dirinya, sama halnya seperti peserta didik dalam merinteraksi dengan teman sebananya yang tidak semua siswa memiliki karakter pemberani sehingga menjadikan dirinya percaya diri. Percaya diri merupakan suatu keyakinan dalam jiwa pada manusia bahwa tantangan hidup harus dihadapi dengan melakukan tindakan (Anggraini \& Perdana, 2019; Suryani \& Gunawan, 2018; Vita, 2016). Kepercayaan diri dapat diartikan sebagai keyakinan seseorang akan suatu kemampuan yang dimilikinya untuk melakukan suatu hal yang ditunjukan oleh dirinya sendiri tanpa adanya keterpaksaan seseorang yang memiliki rasa percaya diri akan merasa lebih mampu dalam mencapai tujuan dan menjalankan apapun dalam menjalani kehidupan (Kamar et al., 2020; Maulida, M., Wati \& An'nur, 2015; Yulianti, 2016). Untuk meningkatkan kepercayaan diri siswa maka, solusi yang diberikan oleh peneliti adalah penerapan metode humanistik.

Penelitan yang dilakukan sebelumnya dengan metode kualitatif lapangan menghasilkan data bahwa strategi, metode, serta perilaku guru dalam pengimplemetasian sangat penting dengan adanya penggunaan metode humanistik yang diterapkan dalam pembelajaran memberikan dampak positif bagi pembelajaran. Adapun dampak positif siswa melaksanakan pembelajaran dengan penerapan metode humanistik dapat membuat siswa merasa nyaman saat belajar, merasa dihargai tidak adanya rasa perbedaan prilaku yang lakukan guru terhadap siswa, siswa bebas dalam mengeskplorasi rasa keingintahuannya tanpa ada rasa ancaman. Selain itu, penelitian lain dalam penulisannya terdapat 
hasil bahwa psikologi humanistik sangat relevan dengan dunia pendidikan karena aliran ini mendorong peningkatan kualitas manusia, sejalan dengan peneliti lakukan yaitu dengan adanya penerapan humanistik non verbal dalam pendidikan menjadikan peserta didik percaya diri yang melahirkan peningkatan mutu kehidupan kualitas manusia (Kristiyani, 2015; Lestariningsih \& Suardiman, 2017; Mudlofir, 2013).

Penelitian ini didukung dengan beberapa penelitian yang relevan, seperti: (1) penelitian yang dilakukan oleh (Vita, 2016), yang memperoleh hasil yaitu terjadi peningkatan sikap percaya diri melalui dreams book bagi siswa; (2) penelitian yang dilakukan oleh (Suryani \& Gunawan, 2018), yang memperoleh hasil yaitu ada hubungan pemahaman diri dengan sikap percaya diri pada siswa; (3) penelitian yang dilakukan oleh (Anggraini \& Perdana, 2019), yang memperoleh hasil yaitu hubungan sikap dan percaya diri siswa pada mata pelajaran IPA. Implikasi penelitian tentang penerapan humanistik melalui non verbal reinforcement ini adalah siswa akan merasa nyaman saat belajar, merasa dihargai tidak adanya rasa perbedaan prilaku yang dilakukan guru terhadap siswa, siswa bebas dalam mengeskplorasi rasa keingintahuannya tanpa ada rasa ancaman.

\section{Simpulan}

Simpulan penelitian lapangan ini adalah bahwa penerapan humanistik melalui non verbal reinforcement dinyatakan dapat berpengaruh terhadap percaya diri siswa dalam pembelajaran. Implikasi penelitian ini adalah siswa akan merasa nyaman saat belajar, merasa dihargai tidak adanya rasa perbedaan prilaku yang dilakukan guru terhadap siswa, siswa bebas dalam mengeskplorasi rasa keingintahuannya tanpa ada rasa ancaman.

\section{Daftar Pustaka}

Amran, Jasin, I., Perkasa, M., Satriawan, M., \& Irwansyah, M. (2019). model pembelajaran berbasis nilai pendidikan karakter untuk generasi indonesia abad 21. lentera pendidikan, 22(2), 233-242. https://doi.org/10.24252/lp.2019v22n2i5

Anggraini, L., \& Perdana, R. (2019). Hubungan Sikap dan Percaya Diri Siswa Pada Mata Pelajaran IPA di Sekolah Menengah Pertama. Spektra: Jurnal Kajian Pendidikan Sains, 5(2), 188-199. https://doi.org/10.32699/spektra.v5i2.103

Dardiri, A., Mujiyono, M., \& Ichwanto, M. A. (2017). Analisis Hasil Uji Kompetensi Guru Sekolah Menengah Kejuran Bidang Keahlian Teknik Bangunan. Teknologi Dan Kejuruan: Jurnal Teknologi, Kejuruan, Dan Pengajarannya, 40(2), 193-203. https://doi.org/10.17977/um031v40i22017p193

Defiyanti, \& Sumarni, W. (2019). Analisis Kemampuan Berpikir Kritis Peserta Didik Pada Penerapan Problem Based Learning Berbantuan Lembar Kerja Peserta Didik Bermuatan Etnosains. Phenomenon, 09(2), 206-218. https://doi.org/10.21580/phen.2019.9.2.4200

Elviana, P. S. O., \& Murdiono, M. (2017). Pengaruh metode sosiodrama terhadap hasil belajar dan sikap tanggung jawab dalam pembelajaran PKn. Jurnal Civics: Media Kajian Kewarganegaraan, 14(1), 33-50. https://doi.org/10.21831/civics.v14i1.14560

Gaol, P. L., Khumaedi, M., \& Masrukan, M. (2017). Pengembangan Instrumen Penilaian Karakter Percaya Diri pada Mata Pelajaran Matematika Sekolah Menengah Pertama. Journal of Educational Research and Evaluation, 6(1), 63-70. https://doi.org/10.15294/jrer.v6i1.16209

Hartiningsih, S. (2015). Revitalisasi Lagu Dolanan Anak dalam Pembentukan Karakter Anak Usia Dini. Atavisme, 18(2), 247-259. https://doi.org/10.24257/atavisme.v18i2.119.247-259

Irawan, E. (2016). Implementasi Penanaman Karakter Melalui Matematika Pada Kurikulum 2013. Ibriez: Jurnal Kependidikan Dasar Islam Berbasis Sains, 1(1), 1-18. https://doi.org/10.21154/ibriez.v1i1.4

Kamar, K., Asbar, M., Purwanto, A., Nurhayat, W., Agistiawati, E., \& Sudiyono, R. N. (2020). Membangun Karakter Siswa Sekolah Dasar Melalui Praktek Pola Asuh Orang Tua Berdasarkan Genetic Personality. JINoP Jurnal Inovasi Pembelajaran), 6(1), 75-86. 
https://doi.org/10.22219/jinop.v6i1.10196

Karom, D., Ruhimat, T., \& Darmawan, D. (2014). Pengaruh Kompetensi Pedagogik Guru Dalam Menerapkan Pembelajaran Kooperatif Berbantuan Media Presentasi Terhadap Hasil Belajar Peserta Didik Pada Mata Pelajaran Matematika. Edutech, 13(2), 274-308. https://doi.org/10.17509/edutech.v13i2.3113

Khodijah, N. (2018). Pendidikan Karakter Dalam Kultur Islam Melayu (Studi Terhadap Pola Asuh Orang Tua, Faktor-Faktor Yang Mempengaruhinya, Dan Pengaruhnya Terhadap Religiusitas Remaja Pada Suku Melayu Palembang). Tadrib: Jurnal Pendidikan Agama Islam, 4(1), 21-39. https://doi.org/10.19109/tadrib.v4i1.1949

Khofiatun, Akbar, S., \& Ramli, M. (2016). Peran Kompetensi Pedagogik Guru Dalam Pembelajaran Tematik Di Sekolah Dasar. Jurnal Pendidikan, 1(5), 984-988. https://doi.org/10.17977/jp.v1i5.6336

Kristiyani, A. (2015). Implementasi Pendidikan Karakter Pada Pembelajaran Bahasa Di Pg-Tpa Alam Uswatun Khasanah Sleman Yogyakarta. Jurnal Pendidikan Karakter, 4(3), 252-263. https://doi.org/10.21831/jpk.v0i3.5630

Labudasari, E., \& Rochmah, E. (2018). Pengaruh Gerakan Literasi Sekolah Terhadap Karakter Mandiri Siswa Di SDN Kanggraksan Cirebon. Premiere Educandum: Jurnal Pendidikan Dasar Dan Pembelajaran, 9(1), 57-63. https://doi.org/10.25273/pe.v9i1.4254

Lestariningsih, N., \& Suardiman, S. P. (2017). Pengembangan Bahan Ajar Tematik-Integratif Berbasis Kearifan Lokal Untuk Meningkatkan Karakter Peduli Dan Tanggung Jawab. Jurnal Pendidikan Karakter, 7(1), 86-99. https://doi.org/10.21831/jpk.v7i1.15503

Maulida, M., Wati, M., \& An'nur, S. (2015). Pengembangan Bahan Ajar Berbasis Pendidikan Karakter Dalam Mendukung Implementasi Kurikulum 2013. Berkala Ilmiah Pendidikan Fisika, 3(1), 1119. https://doi.org/10.20527/bipf.v3i1.760

Morelent, Y., \& Syofiani. (2018). Pengaruh Penerapan Kurikulum 2013 Terhadap Pembentukan Karakter Siswa Sekolah Dasar Negeri 05 Percobaan Pintu Kabun Bukittinggi. Jurnal Penelitian Bahasa Dan Sastra Indonesia, 1(2), 141-152. https://doi.org/10.22202/jg.2015.v1i2.1234

Mudlofir, A. (2013). Pendidikan Karakter: Konsep dan Aktualisasinya dalam Sistem Pendidikan Islam. Nadwa, 7(2), 229-363. https://doi.org/10.21580/nw.2013.7.2.560

Nursa'ban, M. (2013). Peningkatan Sikap Tanggung Jawab Dan Kemandirian Belajar Mahasiswa Melalui Metode Tutorial Di Jurusan Pendidikan Geografi. Jurnal Cakrawala Pendidikan, 3(3), 432-443. https://doi.org/10.21831/cp.v3i3.1630

Pebriana, P. H. (2018). Analisis Penggunaan Gadget terhadap Kemampuan Interaksi Sosial pada Anak Usia Dini. JURNAL OBSESI, 1(1), 1-11. https://doi.org/10.31004/obsesi.v1i1.26

Ponorogo, I. (2016). Implementasi Penanaman Karakter Melalui Matematika Pada Kurikulum 2013. Ibriez: Jurnal Kependidikan Dasar Islam Berbasis Sains, 1(1). https://doi.org/10.21154/ibriez.v1i1.4

Putra, P. (2017). Penerapan Pendekatan Inkuiri Pada Mata Pelajaran IPA untuk Mengembangkan Karakter Siswa di SDN 01 Kota Bangun. Jurnal Madrasah Ibtidaiyah, 3(1), 28-47. https://doi.org/10.31602/muallimuna.v3i1.953

Rizal, S., \& Munip, A. (2017). Strategi Guru Kelas dalam Menumbuhkan Nilai-Nilai Karakter Pada Siswa SD/MI. Al Ibtida: Jurnal Pendidikan Guru MI, 4(1), 45. https://doi.org/10.24235/al.ibtida.snj.v4i1.1462

Saputro, H. B., \& Soeharto. (2015). Pengembangan Media Komik Berbasis Pendidikan Karakter Pada Pembelajaran Tematik-Integratif Kelas IV SD. Jurnal Prima Edukasi, 3(1), 61 - 72. https://doi.org/10.21831/jpe.v3i1.4065

Sari, I. P., \& Syamsi, K. (2015). Pengembangan Buku Pelajaran Tematik-Integratif Berbasis Nilai Karakter Disiplin Dan Tanggung Jawab Di Sekolah Dasar. Jurnal Prima Edukasi, 3(1), 73-83. 
Surya, Y. F. (2017). Penggunaan Model Pembelajaran Pendidikan Karakter Abad 21 pada Anak Usia Dini. Jurnal Obsesi : Jurnal Pendidikan Anak Usia Dini, 1(1), 52-61. https://doi.org/10.31004/obsesi.v1i1.30

Suryani, O. I., \& Gunawan, I. M. (2018). Hubungan Pemahaman Diri dengan Sikap Percaya Diri Pada Siswa Kelas VIII SMPN 7 Woja. Jurnal Kependidikan: Jurnal Hasil Penelitian Dan Kajian Kepustakaan Di Bidang Pendidikan, Pengajaran Dan Pembelajaran, 4(2), 188-191. https://doi.org/10.33394/jk.v4i2.1128

Suwarna, \& Jatirahayu, W. (2013). Pembelajaran Karakter Yang Menyenangkan (Refleksi Sebuah $\begin{array}{llll}\text { Pengalaman). Jurnal } \quad \text { Pendidikan } & \text { Karakter, }\end{array}$ https://doi.org/10.21831/jpk.v0i3.2750

Tisnasari, S. (2017). Analisis kesalahan bahasa pada bangun dan perpaduan leksem bahasa indonesia. Jurnal HandayanI (JH), 7(1), 28-37. https://doi.org/10.24114/jh.v7i1.6572

Vita, Y. (2016). Penguatan Sikap Percaya Diri melalui Dreams Book bagi Siswa Kelas I SDN Tegalombo I Kalijambe Sragen. At-Tarbawi: Jurnal Kajian Kependidikan Islam, 1(2), 123-136. https://doi.org/10.22515/attarbawi.v1i2.169

Widiarti, P. W. (2013). Pendidikan Karakter Berbasis Empati Pada Anak-Anak Usia Sd. Informasi, 39(2), 83-91. https://doi.org/10.21831/informasi.v0i2.4446

Yulianti, N. (2016). Pengaruh Model Inkuiri Terbimbing Berbasis Lingkungan Terhadap Kemampuan Pemahaman Konsep Dan Karakter. Jurnal Cakrawala Pendas, 2(2). https://doi.org/10.31949/jcp.v2i2.329 